\title{
ULUSLARARASI INSAN HAKLARI ANDLAŞMALARININ BAĞDAŞMAZLIĞI SORUNU VE ULUSLARARASI HUKUK
}

\author{
Yrd.Doç. Dr. Mahmut Göçer \\ Kocaeli Üniversitesi \\ Hukuk Fakültesi
}

\section{Özet}

Insan haklarınn uluslararası bir boyut kazanmasina paralel olarak, insan haklan andlaşmalarının büyük bir huzla çoğaldığı görülmektedir.

Bu çoğalma, bazı durumlarda, insan hakları andlaşmalarınun bağdaşmazlığı sorununu da beraberinde getirmektedir. Oysaki, genel uluslararası hukukun normlar çatı̧̧ması kuralları, bu tür bağdaşmazlıklann çözümünde her zaman etkin olamamaktadır. Bu durum, büyük ölçüde, insan hakları andlaşmalanının kendilerine özgü özelliklerinden kaynaklanmaktadır.

The Question of Incompatibility of International Human Rights Treaties and Intemational Law

\section{Abstract}

Paralleling to the internationalisation of human rights, it is to be seen that human rights treaties increase at a great speed. In some cases, this increase brings itself with the question of incompatibility amongst human rights treaties. Be as it may, rules pertaining to the norm conflicts of general international law could not be efficient all the time, in solving such incompatibilities.

This situation mainly arises from the unique characteristics of human rights treaties. 


\section{Uluslararası İnsan Hakları Andlaşmalarının Bağdaşmazlığı Sorunu ve Uluslararası Hukuk}

Insan Haklan Evrensel Bildirisinin kabulünden bu yana, ortak paydaları objektif ve normatif andlaşmalar teşkil etmeleri olan, uluslararası insan haklarının korunması andlaşmalarının büyük bir hızla çoğalması, bir yandan temel hakların korunmasının güçlenmesi bakımından olumlu bir gelişme oluştururken, diğer yandan kaçınılmaz bir biçimde yargıç önünde uygulamada uzlaşım güçlükleri ve hatta çelişkiler yaratma bağlamında bir takım olumsuzlukları beraberinde getirmektedir. Böyle bir gelişmenin ortaya çıkaracağı olumsuzluklar öğretide çok erken tahmin edilmiş ve bazı yazarlar kendi kendine yeterli andlaşma düşüncesinden uzaklaşıldıkça, bu andlaşma ile var olan ve gelecekteki somut uygulamaya dönük diğer çok taraflı antlaşmalar arasındaki ilişkilerin büyük bir önem kazanacağını ve politik ve teknik problemler yaratacağın belirtmişlerdi. ${ }^{1}$

Uluslararası Insan Hakları Hukukundaki bu huzlı gelişimin sebepleri, bir yandan sürekli olarak yeni hak kategorilerinin ortaya çıkması, diğer yandan ise, uluslararası toplumun homojen bir yapı oluşturmaması ve ideoloji farklıliklarının ayn insan hakkının bütün devletlerce ayn şekilde kabul edilmemesi sonucunu doğurmasıdır. ${ }^{2}$

Ancak uluslararası insan hakları hukuku, sadece gelişmekle kalmamakta fakat, aynı zamanda devletlerin iç hukuk düzenine önemi gitgide artan bir etkide bulunmaktadır. Öyle ki, bu hızlı gelişimin iç hukuka etkisi ulusal yargıcı bir insan hakları sözleşmeleri labirenti içine sokmaktadır. Uluslararası insan hakları andlaşmalannın devletlerin iç hukuk düzeninde bağdaştırılması problemi Amerika ve Afrika ülkelerinden daha çok, ülkemizin de dahil olduğu Avrupa temel haklar koruma sisteminde büyük bir önem kazanmıştır. Zira,

1 Bu tür bağdaşmazlık problemlerinin ortaya çıkabileceğini ilk tahmin edenler arasında Fransız hukukçu Rene Cassin bulunmaktadır. Bkz. (CASSIN, 1951: 315).

2 Bu tür farklılıklann en çarpıcı örneklerinden birini, Bağımsız Devletler Topluluğunun, 26 Mayıs 1995'de Minsk'te imzalanan Insan Haklan Sözleşmesi ile kendine özgü bir koruma sistemi meydana getirmesi oluşturmaktadır. 
insan haklarının uluslararası bir boyut kazanması yolunda ilk adımlar, Avrupa Insan Haklarn Sözleşmesinin kabul edilmesiyle Avrupa'da atılmıs ve Avrupa devletleri bu sözleşme yanında, Birleşmiş Milletler çerçevesinde hazırlanan, başta 1966 sözleşmeleri olmak üzere, birçok evrensel insan hakłarı sözleşmelerine taraf olmuşlardır. ${ }^{3}$

Ulusal yargıৎ̧, ve hatta uluslararası yargıç, içerdikleri yükümlülükler tamamen benzer olmayan ve aralarında karşlıklı etkileşime çok elverişli bir insan hakları sözleşmeleri kümesiyle karşı karşıya kalmıştır. Bu sözleşmeler arasındaki etkileşimler bazı hakların tekranı biçiminde olduğu gibi, bazen özellikle hakların tanımı ve bu haklara getirilen sınurlamaların kapsamı bakımından farklıliklar şeklinde de ortaya çkabilmekte ve bu sözleşmelerin uygulamada bağdaştırılmasını gerektirmektedir (COHEN-JONATHAN, 1994: 26; CAPOTORTI, 1968: 123).

Uluslararası andlaşmalar arasında karşılıklı etkileşim ve bağdaşırlık sorunu her ne kadar insan hakları alanuna özgü bir sorun olmasa da, insan hakları andlaşmalarının bağdaşırlı̆ı, uluslararası insan hakları hukukunun genel uluslararası hukuka nazaran arz ettiği bazı özelliklerden dolayı, ayn bir şekilde ele alınmak durumundadır. ${ }^{4}$ Gerçekten de, uluslararası insan hakları andlaşmalan, bir yandan muhataplarının devletler değil de bireyler olması ve diğer yandan da içerdikleri yükümlülükler bakımından karşıllklılık ilkesinin neredeyse tamamen dışlandığı türden andlaşmalardır (VASAK, 1974: 407-409; DHOMMEAUX, 1989: 399-400). ${ }^{5}$ Dolayısıyla, hiçbir taraf devletin, diğer bir taraf devletin, yükümlülüklerine uymadığı iddiasıyla, kendi yükümlülüklerinin gereğini yerine getirememezlik edemeyeceği andlaşmalardır. ${ }^{6}$

Böylece, bütün uluslararası insan hakları normlarının insanın korunması gibi ortak bir amaca yönelmesi ve hizmet etmesi gerçeği göz ardı edilmeksizin, ${ }^{7}$

3 AlHS ile karşılıklı etkileşime en çok elverişli olan ve onun gibi doğrudan uygulanabilir niteliği bulunan, BM Medeni ve Siyasal Haklar Sözleşmesi yakın bir zaman önce ülkemiz tarafindan da imzalanmıştır.

4 Uluslararası insan haklan hukukunun bu özellikleri hakkında aynntılı bilgi için bkz. (VASAK, 1974: 407; SUDRE, 1995; 21).

5 Genel uluslararası hukukun karşlıklılık ilkesinin e Viyana Andlaşmalar Hukuku Sözleşmesi'nin 21. maddesinin insan haklarn sözleşmelerine uygulanamayacağ 1 Avrupa Insan Hakları Komisyonu ve Mahkemesi'nin ilk kararlanından bu yana açıkça dile getirilmektedir: (AlHK, 11 Ocak 1961, Avusturya / Italya, Annuaire volume 4: 139; AlHM, 18 Ocak 1978, Irlanda / Ingiltere, Seri A, No: 25).

61969 Viyana Andlaşmalar Hukuku Sözleşmesi'nin 60. maddesi de bu hususu doğrulamaktadır. Gerçekten de bir andlaşmanun diğer taraf veya taraflarca ihlali halinde, diğer taraflara sona erdirme veya askuya alma hakkı tanyan 1 ila 3'ncü paragraf hükümleri, insani nitelikteki andlaşmalara uygulanamaz (60. madde 5 . paragraf). Isviçre'nin önerisiyle eklenen bu 5. paragraf hükmünün "insan haklan andlaşmalarınu" kapsadiğı gerekçeden anlaşılmaktadır.

$7 \mathrm{Bu}$ ortak amaç, hemen hemen bütün insan haklan andlaşmalannın başlangıç hükümlerinde doğrulanan bir husustur. Bu konuda geniş bilgi için bkz. (CONFORTI, 1998: 21). 
bu andlaşmaların bağdaşmazlığı sorunu, biraz önce de belirttiğimiz gibi, uluslararası insan hakları hukuku çerçevesinde özel bir bağlamda incelenmelidir.

\section{I- ULUSLARARASI INSAN HAKLARI ANDLAŞMALARI ARASINDA BAĞDAŞMAZLIK}

Uluslararası insan hakları normlarının karşılıklı etkileşiminin ve özellikle yarışımın meydana getirebileceği en sakıncalı durum, amaçlan insan haklarının korunmasına optimum bir güvence sağlamak olan, iki insan hakları andlaşması hükümlerinin bağdaşmazlığı halidir. Aslında bu sorun, genel uluslararası hukukta iki andlaşma normlarınun çatışmasına uygulanabilecek belirli ve etkin çatışma kurallarının olmayışının ve böylece uluslararası hukukta bir normlar hiyerarşisi yokluğunun, sadece insan haklarının uluslararası korunması alanına bir yansımasıdır. ${ }^{8}$ Gerçekten de, genel uluslararası hukukta, temel güçlüğün uluslararası hukuk özneleri iradesinin özerkliğinin, andlaşmaların nispi etkisi ilkesiyle uzlaştırılması zorunluluğundan kaynaklanan böyle bir soruna, uluslararası hukuk öğretisinde yazarlarca önerilen çözümlerin hiçbiri tatmin edici ve uygulamayla pek bağdaşır olmadığı gibi, konuyu pozitif hukuk çözümlerine kavuşturmayı amaçlayan 1969 Viyana Andlaşmalar Hukuku Sözleşmesinin esasen 30. maddesinde getirilmiş olan kurallarda, bu alanda uluslararası uygulamanun bütün çözümlerini yansıtmaktan uzaktır. ${ }^{9}$

Insan hakları andlaşmaları arasında böyle bir bağdaşmazlık sorununun, bütün bu andlaşmaların ortak amacının bir minimum standart aracıllğıyla bireyin haklarına optimum güvence sağlamak olduğu gözönüne alındığında, varsayımsal olduğu düşünülebilirse de; bu andlaşmaların güvence altına aldıkları hakların tanımında ve sinırlamaların kapsamındaki farklılkklar, bu durumun varlığının yadsınamayacağı gerçeğini gözler önüne sermektedir. Ayrıca, uluslararası insan haklan andlaşmalarının iç hukuka etkisi ivme kazandıkça, bağdaşmazlık sorunları ile karşılaşılma olasılıkları artacaktır. Kaldı ki, bugün dahi bu tür andlaşmalar arasındaki çelişkiler, bunların çözümü güç olduğundan dolayı, ulusal yarg1 yerleri tarafından yok sayulmakta ve gizlenmektedir.

Farkhı şekillerde ortaya çıkabilen bağdaşmazlık durumların ve bu sorunun çözüm yöntemlerinin incelemeden önce, iki insan hakları andlaşması

8 Uluslararası hukukta etkin çatışma kurallarının olmayışına ilişkin olarak bkz. (QUOCDINH/DAILLIER/PELLET, 1999: 264-265; GÜNDÜZ, 1998: 35; GALLAND, 1993: 73; ROUCOUNAS, 1987: 16).

9 Daha geniş açıklamalar için bkz. (QUOC DINH/DAILLIER/PELLET, 1999: 265; SCIOTTI, 1997: 60; GALLAND, 1993: 64). Esasen, bu hususta Viyana Sözleşmesi'nin 30. maddesi, aynı konu hakkındaki ardıl andlaşmaların çatışması halinde, uygulanması gereken çatışma kurallarına ilişkin hükümler getirmektedir. 
arasında böyle bir bağdaşmazlık durumunun ortaya çlkabilmesi için ne gibi koşullar gerektiğini kısaca belirtmekte yarar görmekteyiz.

\section{BAĞoAŞMAZLIK VE ANDLAŞMALARIN UYGULANABiLIRLIK KOŞULLARI}

İki uluslararası insan hakları andlaşması arasında bir bağdaşmazlıktan söz edebilmek için, her iki andlaşmanın da ulusal yargı yeri önündeki uyuşmazlığa uygulanabilir olması gerekir. Bu uygulanabilirliğin gerekleşmesi ise, birtakım uygulanabilirlik koşullarının sağlanmasını gerektirir.

Bu bakımdan iki insan hakları andlaşması arasında bir bağdaşmazlık durumunun varlığı, her iki andlaşmanın da yargı yeri önündeki uyuşmazlığa konu, kişi, zaman ve yer bakımlarından uygulanabilir olmasına bağlıdır. Yani, zaman ve yer koşulları dışında, her iki andlaşmanın aynı konuyu düzenlemesi ve kişi bakımından ise, ilgili devletin bu andlaşmalara taraf olması, bunlan usulüne uygun bir şekilde onaylayıp iç hukuk düzenine aktarmış olması gerekmektedir (CAPOTORTI, 1968:124).

Bunun yanında, iki andlaşma arasındaki bağdaşmazlığın varlığı her iki andlaşmanın da "doğrudan uygulanabilir" nitelikte olmasın yani, kendiliğinden uygulanabilecek kadar açık ve belirli ve kendi başına bir anlamı olan normlar içermesini gerektirir. ${ }^{10}$

\section{2- BAĞDAŞMAZLIK DURUMLARI}

Iki uluslararası insan hakları normu arasında bir bağdaşmazlıktan söz edebilmek için, iki norm arasında bir çelişki bulunması da gerekir. Bu çelişki, normatif düzeyde iki andlaşma metninin hükümlerinde bir temel hakkın farklı şekilde ele alınmış olmasından, yani farklı terimlerle ifade edilmiş olmasından veya iki farklı temel hakkın düzenlenmis olmasından kaynaklanan açı bir çelişki olabileceği gibi, ilk bakışta fark edilemeyen fakat zamanla iki andlaşmayı yorumlamaya yetkili uluslararası denetim organlarının verdikleri kararlarda ortaya çıkabilen, aynı temel hakkın farklı yorumlarından da kaynaklanabilir.

\section{A- Normatif Düzeyde Bağdaşmazlık}

Uluslararası insan hakları andlaşmaları arasındaki normatif bağdaşmazlık durumları ụ̈ şekilde karşımıza çıkabilir. Bir defa, iki insan hakları andlaşmasında ayn temel hakkın farklı biçimde veya bazı farklılıklarla ifade edilmiş olması, bu andlaşmalardan birinin veya diğerinin uygulanması 10 Genel olarak doğrudan uygulanabilirlik kavramı hakkında bkz. (BYK, 1994:967;
AKILLIOĞLU, 1993: 23). 
durumunda, bu temel hakka farklı bir güvence sağlanmasını getirmektedir. Bu konuda, Birleşmiş Milletler Medeni ve Siyasal Haklar Sözleşmesinin, ceza kanununun geriye yürümezliği hususunda, Avrupa Insan Hakları Sözleşmesinin konuya ilişkin 7. maddesinden daha koruyucu bir hüküm getiren ve "suçun işlenmesinden sonra yeni kanun daha hafif bir cezanun uygulanmasın öngörüyorsa, sanuk bundan faydalanur" hükmünü içeren 15. maddesini örnek olarak gösterebiliriz.

Yine özel hayat gizliliği hakkınun korunmasına ilişkin olarak, Avrupa Insan Haklan Sözleşmesi'nin 8.maddesine göre daha geniş bir koruma sağlayan ve bu Sözleşme'de açıkça belirtilmemiş özel hayat unsurları olarak "kişinin şeref veya toplumda sahip olduğu şöhretin" korunmasını öngören Medeni ve Siyasal Haklar Sözleşmesi'nin 17. maddesi bir başka örnek oluşturmaktadır.

Aynı şekilde, yaşam hakkı konusunda ölüm cezasın hamile kadınlar ve küçükler için yasaklayan Medeni ve Siyasal Haklar Sözleşmesi'nin 6. maddesi (5.paragraf) bu yönüyle Avrupa Insan Hakları Sözleşmesi'nin 2. maddesine göre daha fazla koruyucu bir hüküm olarak görünmektedir.

Gene, sadece Sözleşme'de belirtilen haklar bakımından ayrımcılı̆̆ yasaklayan AtHS'nin 14. maddesine göre, B.M. MSHS.'nin 26. maddesi, kanun
önünde eşitlik ilkesini Sözleşme'de yazllı olmayan haklara da teşmil ederek, daha koruyucu bir hüküm içermektedir. ${ }^{11} \mathrm{O}$ kadar ki, Medeni ve Siyasal Haklar Sözleşmesi'nin ayrımcılık yasağına ilişkin söz konusu hükmü, 1966 tarihli BM. Irk Ayrımcilığının Ortadan Kaldırılması Sözleşmesi'ne göre (1. madde) ayrımcllı̆̆ın daha geniş bir tanımını içermektedir.

Son bir örnek olarak, AlHS'nin 6. maddesinde güvence altına alınan adil yargılama hakkı konusunda daha detaylı güvenceler içeren M.S.H.S'nun 14. maddesini gösterebiliriz. Zira, AtHS'de yer almayan adil yargılama güvenceleri, örneğin "herkesin kendi duruşmasında hazır bulunma hakkı" veya "kişinin kendi aleyhine taniklık etmeye zorlanamaması hakkı", M.S.H.S.'nin 14. maddesinde açkç̧a ifade edilmektedir.

Ancak, belki bundan daha önemli olabilecek başka bir tip normatif bağdaşmazlık, her iki andlaşmada taraf devletlerin, söz konusu bir temel özgürlüğe getirebilmelerine izin verilen kisitlama ve sinurlamaların kapsamından kaynaklanmaktadır. Yani, bir yazarın deyimiyle kisitlamaların tabii olduğu koşulların, her iki andlaşmada düzenleniş şekillerinden ortaya çkan bir bağdaşmazlık söz konusudur. Bu tür bir bağdaşmazlığın, sözkonusu olabileceği somut durumlardan birisi, taraf devletlere bazı hallerde sözleşme

11 Ancak, yakın bir zaman önce imzaya açlan ve henüz yürürlüğe girmemiş bulunan AlHS'ye Ek 12 Nolu Protokol genel bir ayrımcllık yasağı getirerek, bu konuda Sözleşmenin eksikliğini gidermeye çalışmaktadır. 
düzenine aykırı tedbirleri geçici bir süre için alabilme olanağı tanıyan, Avrupa Insan Hakları Sözleşmesinin 15. maddesiyle, gene bu olanağı kabul eden B.M. Kişisel ve Siyasal Haklar Sözleşmesinin 4. maddesi arasındaki farklllıktır. Zira, B.M. Sözleşmesinin 4. maddesi, A.l.H.S'nin 15. maddesinin 2. paragrafında belirtilen dokunulamayacak haklar listesine düşünce, vicdan ve din özgürlüğü gibi üç temel özgürlüğü daha ekleyerek, birey bakımından daha büyük bir güvence alan oluşturmaktadır.

Nihayet üçüncü tip normatif bağdaşmazlık ise, birbiriyle bağdaştırılması zor iki farklı temel hakkı düzenleyen iki insan haklan andlaşması arasında ortaya çkabilir. Yani bir insan hakları andlaşmasınun tanıdığı ve güvence altına aldığı bir temel hakkın başka bir insan haklan andlaşması tarafından tanunan diğer bir temel hakla çelişmesi veya bağdaşmaması durumunda, söz konusu temel hakları içeren insan hakları andlaşmalarının da bağdaşmazlığı söz konusudur. Bir bireyin bir insan hakları andlaşmasinca tanınan bir temel hakkını ileri sürmesi ve söz konusu temel hakkın, diğer bir bireyin ileri sürdüğü ve başka bir insan hakları andlaşmasından doğan bir temel hakla bağdaşmaması durumunda ortaya çıkan bu tip bir bağdaşmazlığın giderilmesi çok güç olup, daha sonra da görüleceği üzere, çözüm yöntemi olarak temel haklar arasında bir hiyerarşinin geliştirilmesini zorunlu kılmaktadır.

Henüz çok sık karşılaşılan bir durum olmasa da, bu tür bir bağdaşmazlığa örnek olarak, 10. madde hükmünde ifade özgürlügünü güvence altına alan AtHS ile, ırk ayrımcilğına karşı korunma hakkınu bir bireysel temel hak olarak tanyan BM Irk Ayrımalığının Ortadan Kaldırılması Sözleşmesi arasında ortaya çıkabilecek bağdaşmazlığı gösterebiliriz. Ülkemizin de taraf olduğu bu iki sözleşme arasında ortaya çkabilecek bağdaşmazlık durumları, daha. sonra da açıklanacağı gibi, sadece kuramsal bir varsayım olmayıp, AİHM'nin 1994 yılında çözme durumunda kaldığı, karşılaş̧labilecek olası bir bağdaşmazlık durumudur.

Ayn şekilde, özel hayata saygı gösterilmesini isteme hakkına daha geniş bir koruma sağlayan BM MSHS (17.madde) ile, ifade özgürlüğüne daha fazla güvence sağlayan AlHS (10.madde) arasında bir bağdaşmazlığın ortaya çıkması olası bir durumdur. Zira bir bireyin Al̈HS'nin tandığı ifade özgürlüğünü, bir başkasının toplumda sahip olduğu şöhreti hedef alarak, kullanmak istemesi ve diğer bireyin de, MSHS'nin tandığı ve şöhretin korunmasını içine alan, özel hayata saygı hakkını ileri sürmesi durumunda, hem iki temel hak arasında, hem de bu hakları içeren ilgili sözleşmeler arasında bir bağdaşmazlık söz konusu olacaktır.

Verdiğimiz örneklerden de anlaşılacă̆ı üzere, insan hakları andlaşmaları arasında normatif bağdaşmazlık sorunu, özellikle B.M. Kişisel ve Siyasal Haklar Sözleşmesi ile Avrupa Insan Hakları Sözleşmesi arasındaki ilişkiler bakımından gündeme gelmiş ve B.M. Sözleşmesinin, AİHS'ne taraf devletlerce onaylanması, 
iki andlaşma arasında ortaya çıkabilecek çelişkileri değerlendiren karşılaştırmalı incelemeler yapılmasına yol açmış ve Avrupa Konseyi Bakanlar Komitesi de, bu muhtemel çelişkileri incelemeyi bir uzmanlar komitesine tevdi etmiştir (COHEN-JONATHAN, 1977: 313). Gerek, sözkonusu Komitenin çalışmalarından, gerekse öğretide yapılan incelemelerden Birleşmiş Milletler Sözleşmesi'nin bazı bakımlardan AlHS'de yer alan yükümlülüklerden daha geniş ve ağır yükümlülükler içerdiği; ayrıca B.M. Sözleşmesinin diğer bazı hükümlerinin de, AlHS. hükümleriyle terim farklılıkları içerdiği ve bunun zaman içinde yorum yoluyla temel bir farklulığa dönüşebileceği sonucu çıkmaktadır (COHEN-JONATHAN, 1977: 317).

Her ne kadar, bu iki evrensel ve bölgesel koruma sistemi arasındaki ilişkiler ve bağdaşmazlık sorunu yakın yıllara kadar gözden uzaklaştı ise de; normatif bağdaşmazlık sorunu başka bir boyutta yeniden karşımıza çıkmış görünmektedir. Sorunun bu güncel boyutu, Sovyetler Birliğinin parçalanmasından sonra Bağımsız Devletler Topluluğu Örgütü'nün ortaya çıkması ve bu örgüt çerçevesinde 26 Mayıs 1995'te imzalanan Bağımsız Devletler Topluluğu Insan Hakları Sözleşmesinin, bu ilişkiler mekanizmasına dahil olmasından kaynaklanmaktadır. ${ }^{12}$ Zira, bu örgüt üyesi devletlerin tamamına yakını, aynı zamanda, Avrupa Konseyi'ne de üye olmuş, diğer yandan da, çoğu hem Bağımsız Devletler Topluluğu Insan Haklan Sözleşmesine hem de A.I.H.S.'ye taraf olmuşlardır. Dolayısıyla, bu devletlerin iç hukukunda iki sözleşme arasında bağdaşmazlık riskleri oluşabileceği, Avrupa Konseyi Genel Sekreterliği'nin, iki raportörü, bu sorunu incelemek üzere görevlendirmesinden de anlaşlmaktadır. ${ }^{13}$

Bağımsız Devletler Topluluğu İnsan Haklan Sözleşmesi, her ne kadar hazırlanı̧ aşamasında Avrupa Sözleşmesinden etkilenmiş görünse de ve hatta Avrupa Sözleşmesinde olmayan, sosyal ve ekonomik haklara yer vermiş olsa da; bazı hükümlerinin, Avrupa Sözleşmesiyle bağdaşmadığını görmekteyiz. Bu durum özellikle, Avrupa Sözleşmesinde daha açlk ve belirli güvencelere kavuşturulmuş bulunan yaşama hakkı, kişi özgürlüğü ve güvenliği, adil yargılama hakkı, ifade özgürlüğü ve özgürlüklere getirilebilecek kısıtlamalar konusunda açıkça göze çarpmaktadır.

\section{B- İçtihadi Düzeyde Bağdaşmazlık}

Iki insan hakları andlaşması arasındaki bağdaşmazlık, sadece bu andlaşmalar arasındaki normatif düzeyde bir çelişkiden kaynaklanmayabilir.

12 Sözkonusu sözleşme hakkında daha geniş bilgi için bkz. (SCIOTTI, 1997: 32).

13 Avrupa Konseyi Genel Sekreterine 1995 yllinda sunulan bu rapor hakknda bkz. (SCIOTTI, 1997: 32). 
Yani, ilk bakışta her iki andlaşmanun güvence altına aldığı hakların tanumlanmasında bir farklılık görünmeyebilirse de zaman içinde bu andlaşmaları yorumlamaya yetkili, uluslararası organların kararlarında aynı temel hakkın daha geniş veya dar yorumlanmasına bağlı olarak içtihadi düzeyde iki andlaşmanın bağdaşmazlığı söz konusu olabilir. Zira, ulusal yargıç, sadece andlaşma metnini değil, fakat, ayn zamanda, o andlaşmayı yorumlamaya yetkili denetim organının, içtihadını da gözönüne almak zorundadir (RIDEAU, 1991: 47; COHEN-JONATHAN, 1977: 321; ROUCOUNAS, 1987: 219). Oysa ki, her iki andlaşmanun da iç hukuka aktarllp bağlayıcı güç kazanmış olduğu durumda, ulusal yargıç her iki andlaşmayı yorumlamaya yetkili denetim organlarınn içtihadlannı ayn ölçüde gözönüne almak durumundadır. Íki denetim organınun, ayn temel hakkı genişlik ve kapsam bakımından farklı yorumlaması yani içtihadlarının çatışması durumunda ulusal yargıç tam bir çıkmazla karşı karşıya bulunacaktır. Bu durum, Avrupa temel hakların koruması sisteminde özellikle, Avrupa Birliği üyesi devletlerin iç hukuklarında daha da karmaşık bir hal almaktadır. Çünkü, bu devletler AiHS'ye taraf olduklarından, söz konusu devletlerin ulusal yargıçları, bu Sözleşmeyi yorumlayıp uygulayan iki ulusal üstü yargı organının, yani AIHM ve ATAD'ın, yorumların ve kararlarını göz önüne almak durumundadırlar. ${ }^{14}$ Ayrica bu devletler, BM MSHS başta olmak üzere, diğer birçok uluslararası insan haklan sözleşmelerine de taraf olmuşlardır. Ülkemizin de, yakın bir zaman önce Birleşmiş Milletler Kişisel ve Siyasal Haklar Sözleşmesini imzaladığı ve Avrupa Birliği'ne aday ülke statüsünde olduğu gözönüne alınırsa, bu karmaşık durum+ iç hukukumuzda da kendini hissettirecektir.

Bu tür, içtihad karşıtlıklarından kaynaklanan bağdaşmazlıkların en önemlilerinden birisi, Birleşmiş Milletler Kişisel ve Siyasal Haklar Sözleşmesinin denetim organı olan B.M. İnsan Hakları Komitesi ile Avrupa İnsan Hakları Mahkemesi arasında yaşanmıştır. Bir Fransız vatandaşının, memur olarak çalıştı̆̆ sırada görevinden alınma işleminin iptali için ulusal yargı yerlerinde açtığı davalarda, Avrupa İnsan Haklar Sözleşmesi'nin 6. maddesinde tanunan adil yarglama güvencelerinden faydalanamadığı iddiasıyla Avrupa Insan Hakları Komisyonu'na yaptı̆̆ başvuru, Komisyon tarafından, "kamu görevine ilişkin uyuşmazlıklar 6. maddede belirtilen medeni nitelikte hak ve yükümlülük çerçevesine girmediği" gerekçesiyle konu bakımından sözleşmeyle bağdaşmaz bulunarak reddedilmiştir(FLAUSS, 1996: 376). Aynı kişi, gene adil yargılama hakkının zedelendiğini ileri sürerek B.M. İnsan Hakları Komitesi'ne başvurmuştur. Oysa ki, Fransız Hükümeti'nin, Komitenin yetkisizliğini iddia

14 ATAD' 'n AlHS'yi özerk biçimde yorumlamasından kaynaklanan sorunlar için bkz. (COHEN-JONATHAN, 1996: 125; FLAUSS, 1999: 147; GÖÇER, 2000: 386; RIDEAU / RENUCCI, 1997: 95). 
eden cevabında belirtildiği gibi, görünüşe göre B.M. Kişisel ve Siyasal Haklar Sözleşmesi'nin adil yargılama hakkına ilişkin 14. maddesi A.l.H.S'nin 6. maddesiyle ayn terimlerle bu hakkı ifade etmis, yani "medeni nitelikli hak ve yükümlülükler" kavramina atıfta bulunmuştur (FLAUSS, 1996: 377).

Ancak, her iki sözleşmede aynı terimler kullanulmış olsa da, söz konusu temel hak, Komisyon'un veya Komite'nin yorumuna bağlı olarak genişleyebilecektir. Nitekim, Komite, "medeni nitelikli hak ve yükümlülük kavramunun 14. maddede taraflardan birinin konumundan daha çok, söz konusu hakkın niteliğine dayandığınu" belirterek kamu görevine ilişkin uyuşmazlıkların medeni nitelikli hak ve yükümlülüklere ilişkin bir uyuşmazlık oluşturduğunu kabul etmiştir (FLAUSS, 1996: 377). Her ne kadar, Avrupa Insan Haklar Komisyonu ve Mahkemesi daha sonra bu iştihadın değiştirerek, 6. madde güvencelerinin kamu görevi uyuşmazlıklarına uygulanabilir olduğunu kabul etmişler ise de, verdiğimiz örnek, nadir de olsa bu tür karşitlıkların ulusal yargıcı bir bağdaşmazlık durumuyla ve bir ikilemle karşı karşıya brrakabileceğini göstermektedir. (AlHM, 26 Ekim 1995, Vogt. C. Allemagne, Revue Trimestrielle des Droits de I'Homme (RTDH), 1996, s.412).

Bu çeşit içtihad karşıtlıkları, aynı Avrupa Insan Hakları Sözleşmesini yorumlayan ve biri bu sözleşmenin resmi yorumcusu olan, Avrupa Insan Hakları Mahkemesi'yle kendini bu sözleşmenin rakip yorumcusu olarak gören ve sözleşmeyi özerk bir şekilde yorumlayan Avrupa Topluluğu Adalet Divanu arasında daha sık ve yoğun olarak yaşanmakta ve bu durum, ulusal yargıçlanı tam anlamıla bir kararsızlığa itmekte ve onları aym temel hakkın farklı yorumlarıyla karşı karşıya burakmaktadır (COHEN-JONATHAN, 1996: 126). Avrupa Topluluğu Adalet Divanı'nun 1989 'da sözleşmeyi 8. madde dolayısıyla farklı yorumlamasıyla başlayan, ve zaman içinde diğer maddeleri de içine almaya başlayan, ve hatta, Amsterdam Andlaşması'nun, Divan'ın yetki alanun genişletmesiyle ivme kazanan bu sürę̧, bir yanda, sözleşmesinin resmi yorumcusu olan AlHM'nin yorumu, diğer yanda ise, Topluluk Hukukunun ağırlığını ve otoritesini arkasına alan ATAD'ın yorumu olmak üzere, ulusal yargıcı, bazen aynı temel hakkın iki farklı uygulamasıyla karşı karşıya bırakmakta ve bu durum, çözümü çok güç problemler yaratmaktadır. Kaldı ki, ATAD aynı tutumu B.M. Sözleşmesi bakımından da sergilemektedir. ${ }^{15}$

Bu tür bir içtihadi bağdaşmazlığın güzel bir örneğini AlHM'nin 1992'de konut donulmazlığına ilişkin olarak verdiği bir kararında (A.l.H.M, 16 Aralık 1992, "Niemietz" Serie A, No: 251-B) konut dokunulmazlığı hakkınun iş yerlerini de kapsayan temel bir hak olduğunu ve dolayısıyla Sözleşme'nin 8. maddesinin

15 Gerçekten de ATAD, BM Medeni ve Siyasal Haklar Sözleşmesi'ni kendi yorumuyla gözönüne almaktadır. ATAD'ın bu tutumu için bkz. (FLAUSS, 1999: 148; GÖÇER, 2000: 387; WASCHMANN, 1997: 885). 
getirdiği korumanın iş yerlerini de kapsadığın belirtmesine karşılık, ATAD'ın 1989 yllında ayn temel hakka ilişkin olarak verdiği kararda (ATAD, 21 Eylül 1989, "Hoechst", Rceueil, s.2859) 8. maddenin güvence altna aldığı konut dokunulmazlığı hakkınun iş yerlerini kapsamadığın dile getirmesinde görmek mümkündür.

ATAD insan hakları sözleşmelerini özerk bir biçimde yorumlama ve böylece aynı temel hak dolayısıyla içtihad bağdaşmazlıklarına yol açma konusundaki tutumunu BM MSHS bakımından da sergilenmektedir. Yüksek Mahkeme özellikle yakın bir zaman önce verdiği bir kararda, BM Insan Haklan Komitesi'nin cinsiyet ayrımcilğı bakımından MSHS'nin 26.maddesinin kapsamına ilişkin olarak verdiği yorumu kabul etmediğini açıkça dile getirmiştir(ATAD, 17 Şubat 1998 "L.Grant" Recueil, s.636).

Insan hakları andlaşmaları arasındaki bağdaşmazlık durumlarının sadece teorik bir olgu değil, uygulamada karş̧laşılan durumlar olduğu gerçeği zorunlu olarak, bu gibi durumların önlenmesi ve çözümüne ilişkin bir takım yöntemler aramaya zorlamaktadır.

\section{II- ULUSLARARASI INSAN HAKLARI ANDLAŞMALARI ARASINDAKI BAĞDAŞMAZLIĞIN ÖNLENMESI VE ÇÖZÜMÜ}

Uluslararası insan hakları normları arasındaki bağdaşmazlığın önlenmesi sadece ulusal yargıcın görevi olmayıp, bu, aynı zamanda bu andlaşmaları hazırlayanların ve aynı şekilde, bu andlaşmalara taraf olan devletlerin de bir ödevidir. Ancak, görüleceği gibi buradaki çözümler, genel uluslararası hukuk çözümlerinden uzaklaşabilmektedir.

\section{BAĞDAŞMAZLIĞıN ÖNLENMESINE İLIŞKIN YÖNTEMLER}

Insan hakları andlaşmaları arasındaki çelişkilerin önlenmesine ilişkin, hepsi ayn ölçüde etkin olmasa da, çeşitli yöntemler geliştirilmiştir. Bunların en önemlileri olarak görünen normatif ve içtihadi uzlaştırma uygulamada sıkça karşılaşılan yöntemlerdir.

\section{A-Normatif Uzlaştırma}

Normatif uzlaştırma, söz konusu insan hakları andlaşmaları metinlerinin birbirlerine yapacaklan yollamalarla, ya hazırlanı̧ aşamasında andlaşmayı hazırlayanların gerçekleştirecekleri ya da devletlerin andlaşmaya taraf olurken, bir takım yöntemlerle yapacakları metinsel eşgüdümü ifade eder (COHEN -JONATHAN, 1977: 323; NUSS, 1996: 418). 
Bu çeşit bir uzlaşturma, yeni bir insan hakları andlaşması hazırlayanların, bu andlaşmayla daha öncekiler arasında çelişki oluşmaması açısından, diğer uluslararası insan hakları andlaşmaların gözönüne almalarını.gerektirir. Bu, tam anlamıyla, ilgili uluslararası örgütler arasında bir işbirliği sürecidir. Amerikan İnsan Hakları Sözleşmesi'ni hazırlayanlar, başta 1948 Evrensel Insan Hakları Bildirisi olmak üzere A.I.H.S. ve diğer BM. sözleşmelerini gözönüne almışlardır. ${ }^{16}$ Gene, Avrupa Sosyal Şart, Uluslararası Çalışma Örgütü'nün desteğiyle hazırlanmıştır. Söz konusu eşgüdüm ve işbirliği, sadece bir yakınlaşma anlamında olmayıp, tanunan hakların içeriğini de ilgilendirmekte, hatta bazen, kullanulan terimler bile ayn olmaktadır. Bu tür metinsel yollamalar, bölgesel sözleşmeler arasında olabileceği gibi, bölgesel sözleşmelerle, evrensel sözleşmeler arasında da olabilmektedir.

Uluslararası insan hakları hukukunun amacı bireyin temel haklarınin en etkin biçimde korunması olduğuna göre, uluslararası insan hakları normları arasındaki bağdaşmazlık sorunlarının mümkün olduğu ölçüde önlenmesi kaçınılmazdır. İste bu zorunluluk, insan hakları andlaşmalarını hazırlayanları, söz konusu andlaşmaların çelişmesi durumunda hangisinin uygulanacağın veya uygulanması gerektiğini belirten "kayıtlar" koymaya itmiştir.

Gerçekten de, bir insan hakları andlaşmasın hazırlayanların, bu andlaşmaya, bu tür andlaşmaların uygulanma önceliği sırasının belirlenmesine ilişkin bir takım hiyerarşik ölçütler koyabilmeleri olanağı Viyana Andlaşmalar Hukuku Sözleşmesi tarafından da öngörülmüştür. Bu sözleşmenin 30. maddesinin 2. Paragrafi; "Bir andlaşma, bir önceki veya sonraki andlaşmanın hükümlerine tabi olduğunu veya onlarla bağdaşmaz sayılamayacağın belirttiği zaman, o diğer andlaşmanın hükümleri üstündür," hükmünü içermektedir.

Bireyin koruması bakımından en elverişli andlaşma hükmünün uygulanması gerektiği düşüncesinden hareket eden, ve bir insan hakları andlaşmasına taraf devletlerin, varolan veya gelecekteki diğer insan hakları andlaşmalarına nazaran, söz konusu andlaşmadan doğan yükümlülüklerinin kapsamını ve içeriğini belirginleştirdikleri bu tür hükümlere "bağdaşırlık kayitları veya beyanları" denmektedir (SCIOTTI, 1997: 47; QUOC DINH/DAILLIER/PELLET, 1999: 265). Bu tür kayıtların amac, iki andlaşmanın eş zamanlı olarak uygulanması gereken durumlarda, içinde yer aldıkları andlaşma yerine, bireye daha elverişli hükümler içeren diğer andlaşmanın uygulanmasın sağlamaktadır. İ̧inde yer aldığı andlaşma yerine, daha fazla koruma sağlayan başka bir andlaşmanın uygulanmasına yönelik bu tür kayıtları çoğu insan hakları sözleşmelerinde bulmak mümkündür.

Insan hakları andlaşmalarınun bağdaşmazlığı durumunda hukuken kavranılabilir ve uygulanabilir en iyi çözüm olarak bazı yazarların üzerinde

16 Bu sözleşmeyle ilgili ayrıntılı açıklamalar için bkz. (GROS-ESPIELL, 1987: 167). 
ssrarla durduğu (COHEN-JONATHAN, 1995: 120) en elverişli hükmün uygulanması yöntemi; açık bir şekilde AlHS'nin "Iş bu sözleşmenin hükümlerinden hiçbiri, her âkid Tarafın kanunlarına veya bu devletin taraf olduğu diğer bir Sözleşmeyle tanınabilecek insan haklarını sınurlayıcı veya ihlâl edici şekilde yorumlanamaz" hükmünde veya B.M. Işkencenin Önlenmesi Sözleşmesi 17. maddede "Bu sözleşme, özgürlükten mahrum edilen kişilere daha büyük bir koruma sağlayan uluslararası andlaşma hükümlerini ihlâl etmez" hükmünde karşımıza çıkmaktadır. ${ }^{17}$

Buna karşın, sadece diğer andlaşmaları değil, teamül niteliğindeki uluslararası yükümlülükleri de kapsayıcı nitelikte bağdaşırlık kayıtlarına rastlamak mümkündür. Bu tür kayıtların en önemlilerinden biri, BM. K.S.H.S'nin 5. maddesinde yer almakta ve "Bu Sözleşmeye taraf olan herhangi bir devlette yasa, örfî düzenleme ya da teamül yoluyla tanınmış ya da mevcut olan insan haklarından hiçbiri, bu Sözleşmenin böyle hakları tanımadığı ya da daha sınurlı ölçüde tanıdığı gerekçesiyle sınırlanamaz veya bunlara aykırı şekilde hareket edemez" hükmünü içermektedir. ${ }^{18}$

Bir kaç örnek vermeye çalıştı̆ımız, bu tür bağdaşırlık kayıtları, bunları içeren andlaşmaların doğrudan uygulanabilir niteliğe sahip olması durumunda, ulusal yargıç için bir bağdaştırma yöntemi olabilecektir. Aynca, bu tür kayıtların bir bağdaştırma yöntemi olarak kullanilmasında en etkin rolü ulusal yargıৎ̧ üstlenmek durumundadır(DE MEYER, 1990: 125). Gerçekten de, öğretide hakłı olarak belirtildiği gibi, uluslararası denetim organlarının bu kayıtları uygulama bakımından bir yetkisi yoktur. Yani, bu organlar devletin iç hukukunda uygulanabilir başka bir Sözleşmenin daha koruyucu olup olmadığını takdir edecek konumda değildir. Bunlar, sadece denetlemekle görevli kılındıkları andlaşma bakımmindan yetkilidirler (DE MEYER, 1990: 125-126; SCIOTTI, 1997: 50).

En elverişli hükmün uygulanması ilkesi her ne kadar insan hakları andlaşmaları arasındaki bağdaşmazlıkların önlenmesi bakımından önemli bir teknik oluştursa da, bu tür kayıtları içermeyen insan hakları andlaşmaları da mevcuttur. ${ }^{19}$ Böyle bir durumda, ulusal yargı̧̧ bu yolda bir bağdaşırlık hükmünün yokluğuna rağmen, daha koruyucu olan Sözleşmeyi uygulayabilecek midir? Yani, daha açı ifade. etmek gerekirse, en elverişli hüküm ilkesi evrensel geçerliliği olan genel bir prensip niteliğine sahip midir?

17 Sözkonusu bu hüküm ve AIHS'nin 53. maddesi hükmü dışında, Amerikan Insan Haklan Sözleşmesi'nin 29. maddesinde ve Avrupa Sosyal Sartı'nın 32. maddesinde aynı nitelikte hükümler yer almaktadır.

18 Benzer bir hüküm BM Çocuk Haklan Sözleşmesi'nin 41. maddesinde yer almaktadır.

191985 tarihli Afrika Insan ve Halklar Hakları Şartı ve 1948 tarihli Soykırımın Önlenmesi Sözleşmesi bu tür kayıtlar içermeyen andlaşmalardır. 
Öğretide çoğu yazar, insan hakları andlaşmaları bakımından, böyle bir bağdaşrlık hükmünün yokluğunda dahi en elverişli andlaşma normlarının uygulanmasın öngören genel bir ilkenin varolduğunu belirtmektedir (ROUCOUNAS, 1987: 212; COHEN-JONATHAN, 1977: 323). Böyle bir genel ilkenin varlı̆ını ispatlamak amacıyla bazı yazarlar, ilgili devletin en genis korumayı sağlayan kuralı uygulaması durumunda bağdaşmaz andlaşmalardan herhangi birinin ihlâlinin sözkonusu olmadığın belirtmektedir (SCIOTTI, 1977: 56; COHEN-JONATHAN, 1977: 323). Zira, ilgili devlet, en elverişli hükmü uygulamakla her iki andlaşmadan doğan yükümlülüklerini yerine getirmiş sayılacaktır; çünkü, her iki andlaşma bakımından da minimum koruma standardının gereklerine sayg1 göstermiş olacaktur (COHEN-JONATHAN, 1977: 323-324). Bu gerekçelerden başka, çok sayıda insan hakları sözleşmesinin sözkonusu ilkeye yer verdiğini gözönüne alarak, bu konuda bir genel kan (Opinio Juris) olduğu da söylenebilir.

Ancak, uluslararası örgütlerin söz konusu işbirliği ve eşgüdüm çabalan, her zaman sonuç veremediğinden normatif uzlaştırma görevini bir ölçüde devletler üstlenebilir. Ilgili devletin, bu konuda yapabileceği şey, ya yeni taraf olacağı andlaşmanun daha önceki bir andlaşmayla çelişmesi durumunda yeni andlaşmaya taraf olmamak, ya da yeni andlaşmanın kendi iç hukuk düzeninde daha önceki bir andlaşmayla çelişmemesi için, yeni andlaşmaya bu yolda bir çekince koymaktır (COHEN-JONATHAN, 1994: 27; SCIOTTI, 1997: 42). Her ne kadar, çekinceler insan hakları andlaşmaları için, pek uygun olmayan bir yöntem oluştursa da, iki uluslararası insan hakları normu arasında bir bağdaşmazlık durumunun ortaya çıkmasına engel olabilir.

Çekincelerin, bu tür bir bağdaşmazlık durumunu engelleyebileceğinin, güzel bir örneğini İsviçre'nin BM. K.S HS.'nin 26. maddesine koyduğu çekincede görmek mümkündür. Sözkonusu çekince, "herkesin kanun önünde eşitliği, Sözleşme'de içerilen diğer haklarla ilişkili olarak, güvence altına alınacak'tır." hükmüyle, uluslararası insan haklan andlaşmalarında farklı koruma düzeyleri yaratmamak için, tabii bu arada özellikle söz konusu 26. maddenin kapsamının A.l.H.S'nin 14. maddesinden daha geniş algılanmasını önlemek için konulmuştur. ${ }^{20}$ Böylece, 26. maddenin kapsamı hakkında, A.I.H.S. ile ilişkilerden kaynaklanabilecek belirsizlikler Isviçre bakımından ortadan kaldırılmıştır (MALINVERNI, 2000: 59-60).

Ancak, görüldüğü gibi çekince yoluyla uzlaştırma yönteminde, söz konusu uzlaştırma daha yüksek bir koruma düzeỵi içeren sözleşmenin aşağıya çekilmesi yoluyla gerçekleştirilmekte, bu ise, insan haklarının korunmasının

20 Sözkonusu çekince ve Isviçre Federal Mahkemesi'nin bu çekinceyi geçerlilik denetimine tabi tutarak, sözleşme'nin konu ve amacina uygun bulması hakkında bkz. (MALINVERNII, 2000: 59). 
güçlendirilmesi amacıyla bağdaşmamaktadır. Kaldı ki, çekinceler, klasik karşılıklılık ilkesinin geçerli olmadığı insan hakları alanı bakımından uygun bir yöntem oluşturmamaktadır. O halde, bu tür bağdaşmazlık problemlerini, çözme görevi yargıca, daha doğrusu uluslararası yargıca düşmektedir.

\section{B-İçtihadi Uzlaştırma}

Uluslararası insan hakları andlaşmaları arasındaki bağdaştırma görevini, bir andlaşmayı diğerinin ışığında yorumlayarak, gitgide büyük ölçüde uluslararası yargıç üstlenmektedir (NUSS, 1996: 430; COHEN-JONATHAN, 1994: 28). Bu amaçla, uluslararası yargıç, önüne gelen uyuşmazlıklarda verdiği kararlarla, bağdaşmaz gibi görünen andlaşmaları, uzlaştırıcı bir yoruma tabi tutmakta ve bu yorum da kural olarak, ulusal yargıc bağlamaktadır.

Bu tür bir uzlaştırma, özellikle Avrupa temel haklar sistemiyle. Birleşmiş Milletler sistemi arasında bağdaşmazlık problemlerinin önlenmesinde, AlHS denetim organlannun ve BM. Insan Hakları Komitesi'nin kullandığı bir koordinasyon unsuru olarak ortaya çıkmaktadır. Bu çerçevede, Avrupa Sözleşmesi denetim organlarının içtihadı diğer insan hakları andlaşmaları çerçevesinde oluşan çözümleri özellikle de; BM. Kişisel ve Siyasal Haklar Sözleşmesini gözönüne almaktadır. Bu amaçla, A.I.H.M. ve Komisyonu, Sözleşmenin 6. maddesinde belirtilen adil yarglama güvencelerini, bu konuda daha detaylı haklar içeren K.S.H.S.'in 14. maddesinden esinlenerek, tamamlamıştır (COHEN-JONATHAN, 1994: 28). Aynı şekilde, söz konusu organların içtihadı, BM Sözleşmesini gözönüne alarak, bu sözleşmesinin 17. maddesinde tanunan şeref ve haysiyetin korunması hakkınun, özel hayata saygı hakkı içinde örtülü olarak yeraldığın kabul etmiştir. ${ }^{21}$ Gene, yakın bir zaman önce, A.I.H.M. BM. Iş̧encenin Önlenmesi Sözleşmesi'nin 1. maddesinde yeralan işkencenin tanımını gözönüne alarak, bir kamu görevlisinin, güvenlik güçlerince gözaltına alınan bir kişiye tecavüz olayını işkence olarak nitelemiştir (AlHM, 25 Eylül 1997, "Aydın c. Turque", 1996/676/866).

Avrupa Sözleşmesi denetim organları, diğer insan haklan andlaşmaların, kendi yorumların güçlendirmek için kullandıkları gibi, Sözleşmenin boşluklarını doldurmak için de gözönüne almaktadırlar. Bu anlamda, AlHM. örneğin, aile hayatı kavramına verdiği yorumu güçlendirmek için BM. Çocuk Hakları Sözleşmesi'nin 7. maddesindeki "çocuğun ailesi tarafından yetiştirilme" hakkına ilişkin hükmü kullandığı gibi; A.l.H.S'de ismin korunmasına ilişkin açık bir hüküm olmamasından kaynaklanan boşluğu, bir yandan BM. Çocuk Hakları Sözleşmesi'nin 8. maddesine, diğer yandan da K.S.H.S'nin 24. ve Amerikan

21 Sözkonusu içtihadi sistematik biçimde ele alan bir çalş̧ma için bkz. (COHEN-JONATHAN, 1994). 
Insan Hakları Sözleşmesi'nin 18. maddesine yollama yaparak, doldurma yoluna gitmektedi r(AlHM, 22 Şubat 1994, "Burghartz", Seri A, No: 280 B, 26 Mayıs 1996 "Keegan", Seri A, No: 291). Ancak, sözkonusu denetim organlarınn, diğer insan hakları andlaşmaların gözönüne almaları, çoğu zaman, Sözleşmedeki bir hakkın uygulama alanın genişletmek için olduğu halde, bazı durumlarda bu hakkın sınırlanması amaciyla olabilmektedir. Bu durumun, göze çarpıcı bir örneğini A.l.H.M'nin, BM. Irk Ayrımallğının Ortadan Kaldırılması Sözleşmesi'ni gözönüne aldığı ve A.t.H.S'nin 10. maddesiyle bağdaştırmak durumunda kaldığı, bir davada verdiği kararda görmek mümkündür. Bu kararda, Mahkeme A.t.H.S'nin 10. maddesinin, B.M. Irk Ayrımcilı̆̆ının Önlenmesi Sözleşmesince güvence altuna alınan, ırk ayrımcillğına karşı korunma hakkını sınırlayacak bir biçimde yorumlanamayacağını belirterek, Sözleşmedeki ifade özgürlüğünü, iki andlaşmayı bağdaştırmak pahasına sınırlama yoluna gitmiştir (AIHM, 21 Eylül 1994, "Jersild c. Danemark", Seri A, No: 298).

Her halde, AİHS denetim organlarının, diğer insan hakları andlaşmalarını, Avrupa Sözleşmesiyle, bu andlaşmalan bağdaştırma amacıyla gözönüne almaları artık genel kabul gören bir yorum prensibi olarak kabul edilmekte ve bu içtihad çizgisi ulusal yargı yerlerince de izlenmeye başlamaktadır (COHEN-JONATHAN, 1995: 120). Ancak, uluslararası yargıcın, bu çeşit bir uzlaşturmayı gerçekleştirmesi, önüne bu türden bir uyuşmazlık gelmesine bağlıdır. Dolayısıyla, bu çeşit bir görevi sistematik olarak uluslararası yargıcın yerine getirebilmesi için daha radikal mekanizmalara gereksinim duyulmaktadır. Bu mekanizmalardan biri, şu anda Avrupa Topluluk Hukukunda yürürlükte olan, ulusal mahkemelerin ATAD'a yorumsal başvuru yoluyla başvurarak, topluluk hukukunun yorumunda karşlaşlan sorunları ATAD'ın çözmesine benzeyen, bir yorumsal başvuru sisteminin A.I.H.S. çerçevesinde uygulanması olabileceği gibi, Avrupa Topluluğu Andlaşmasi'nın yeni versiyonundaki 300. maddesinden esinlenerek, A.l.H.S'ye taraf bir devletin, yeni bir insan hakları andlaşmasına taraf olacağı zaman A.I.H.M'ye başvurarak, O'nun her iki sözleşmenin bağdaşırlığı hakkında görüşünü alması ve ona göre, hareket etmesi olabilir. ${ }^{22}$ Ancak, AlHS'ye ekli ve denetim mekanizmasında büyük değişiklikler gerçekleştiren 11 nolu protokolün kabulünden sonra dahi, yorumsal başvuru ve AtHM'ye sistematik başvuru gibi önerilerin henüz teorik bir düşünce olarak kaldığın görüyoruz.

Buraya kadar incelemeye çalıştığımız, gerek normatif uzlaştırma gerekse içtihadi uzlaştırma yöntemleri, insan haklan andlaşmaları arasındaki

22 AT Andlaşmasínun söz konusu 228. madde (yeni versiyon 300. madde) hükmüne göre, Topluluğun bir andlaşmayı akdetmesinden önce, Konsey, Komisyon veya bir üye devlet Adalet Divaninın bu konuda görüşünü olabilir. Eğer görüş olumsuz ise, ilgili andlaşma ancak AT Andlaşmasının revizyonuyla yürürlüğe girebilir. Bu konuda bkz. (PAZARCI, 1981: 391). 
bağdaşmazlıkların önlenmesinde, etkinliği sınurlı birer yöntem olup, her durumda bağdaşmazlı̆̆ı önleyememektedir.

Gerçekten de, büyük ölçüde uluslararası yargıcın uyguladığı bir yöntem olan içtihadi uzlaşturma yönteminde yargıç, ayn temel hakkı bazı farklılıklarla düzenleyen iki insan hakları andlaşmasını uzlaştırıcı bir yoruma tabi tutarak, yorum yoluyla bu farklılıkları gidermeye çalı̧̧makta ve böylece bir bağdaşmazlık durumunun ortaya çıkmasını önlemektedir. Ancak, bu çeşit bir uzlaştırma, farklı iki temel hakkı düzenleyen iki insan hakları andlaşmasının bağdaşmazlığı durumunda, böyle bir bağdaşmazlığın yorum yoluyla giderilmesi çok güç veya olanaksız olduğu için, etkin bir yöntem oluşturmaz.

Kaldı ki, daha önce de belirttiğimiz gibi, bu tür bir uzlaştırma görevini uluslararası yargıcın sistematik olarak yerine getirebilmesine olanak verebilecek köklü mekanizmalar şu an için mevcut değildir.

Diğer yandan, ulusal yargıcın kullandığı en elverişli hükmün üstünlüğü ilkesi, her ne kadar teorik olarak bağdaşmazlı̆ıı önlenmesinde etkin bir kural olsa da, bu kuralin uygulanması bakımından iki temel sorunla karşılaşılmaktadır.

Bir defa, bu yöntemi uygulayan yargı̧ için, her durumda birey bakımından iki andlaşma hükmünden hangisinin daha koruyucu olduğunu tespit etmek kolay olmamaktadır (COHEN-JONATHAN, 1994:30). Zira, ayn temel hakkı düzenleyen iki insan hakları andlaşmasının hükümleri arasındaki farklılık, basit bir koruma düzeyi farklılı̆ından ileri giden, bir koruma tekniği farklılığı olabilir. Yani söz konusu temel hak, bası bakımlardan bir andlaşmada daha iyi korunuyorken, bazı bakımlardan ise diğer andlaşmada daha fazla koruma görüyor olabilir (DUBOUIS, 1977:305; COHEN-JONATHAN,1977: 323).

Böyle bir duruma örnek olarak, AlHS'nin 2.maddesinde ve MSHS'nin 6.maddesinde düzenlenen yaşama hakkını göstermek mümkündür. Gerçekten de, bir yandan ölüm cezasını hamile kadınlar ve küçükler için yasakladığından dolayı MSHS hükümleri daha koruyucu görünüyorken, diğer yanda AlHS, bu hakka getirilebilecek sinılamalar konusunda daha kısıtlayıcı hükümler içerdiğinden, daha iyi bir koruma sağlıyor gibi görünmektedir.

Yine AİHS'ye Ek 1 No'lu Protokol'ün 2. maddesindeki, ana babanın çocuğun eğitim ve öğretimini kendi dini ve felsefi görüşlerine göre temin etmek hakkına sahip oldukları hükmünün, ülkemizin de taraf olduğu BM Çocuk Hakları Sözleşmesi'nin 14. Maddesinde çocuğa tanınan din, vicdan ve düşünce özgürlüğü ile, çocuğun yararı bakımından, bağdaştırılması yargıç için zor görünmektedir.

Ikinci olarak, birbiriyle çelişen iki farklı temel hakkı düzenleyen iki insan hakları andlaşması arasındaki bağdaşmazlık durumunda, en elverişli hüküm 
ilkesinin önleyici bir yöntem olarak etkin olması söz konusu değildir. Çünkü bu durumda, bir bireyin bir insan hakları andlaşmasınca tanınan temel hakkının, diğer bir bireyin ileri sürdüğü ve başka bir insan hakları andlaşmasınca tanunan farklı bir temel hakla çelişmesinden kaynaklanan bir bağdaşmazlık sözkonusu olup, bu çelişki, örneğin temel haklar hiyerarşisi gibi, bir takım başka yöntemlerle aşılmaksızın, andlaşmalar arasındaki bağdaşmazlığın giderilmesi mümkün olmayacaktır. Daha önce verdiğimiz, ırk ayrımcliğına karşı korunma hakkı ile ifade özgürlüğü arasındaki veya özel hayata saygı hakk ile ifade özgürlüğü arasındaki çelişki örnekleri söylediklerimizi doğrular niteliktedir.

\section{2- BAĞDAŞMAZLIĞIN ÇÖZÜMÜ}

Yukarıda açıklamaya çalıştı̆̆ımız gibi, gerek normatif uzlaştırma ve gerekse içtihadi uzlaştırma yöntemleri, yargıcın her durumda bağdaşmazlı̆̆ önlemesine olanak vermemektedir. Önleyici yöntemlerin etkin olmadığı işte bu gibi durumlarda yargı̨̧, bağdaşmazlığı önleme düşüncesini terkederek, onu çözmeye yönelik yöntemler aramak durumundadır. Yargıç böyle bir durumda bağdaşmazlığı çözerken, Viyana Andlaşmalar Hukuku Sözleşmesi'nin öngördüğü normlar çatışması kurallarından veya uluslararası insan hakları hukukunun kendine özgü çözümlerinden yararlanacaktır.

\section{A-Viyana Andlaşmalar Hukuku Sözleşmesinin Öngördüğü Normlar Çatışması Kuralları}

Viyana Andlaşmalar Hukuku Sözleşmesi iki uluslararası norm veya andlaşmanun çatışması durumuna ilişkin olarak, bir takım kurallar getirmiş olsa da, böyle bir durumda yargıç, uluslararası andlaşmalar arasında tam anlamıyla bir hiyerarşi bulunmamasından ve Viyana Sözleşmesi kurallarının da insan hakları konusuna çok fazla uyumlu olmamasından ötürü, çözümü güç bir sorunla karşı karşıya gelecektir (SCIOTTI, 1997: 59; DHOMMEAUX, 1989: 399-400).

Gerçekten de, konumuzu en çok ilgilendiren Viyana Sözleşmesi'nin 30. maddesi, öncelikle 3. paragrafta önceki andlaşmaya taraf devletlerin hepsinin aynı zamanda sonraki andlaşmaya da taraf olması varsayımın düzenlemekte ve sonraki andlaşmanun üstünlüğünü (lex posterior derogat priori) kabul etmektedir.

Oysa ki, bu çatışma kuralı her ne kadar uygulanabilir bir kural olsa da, insan hakları bakımından çok fazla bir önem taşımamaktadır. Zira iki insan hakları andlaşması taraflarının bütünüyle aynı olması çok sık rastlanılan bir durum değildir. Ayrıca, sonraki andlaşmanun üstünlüğü ilkesinin içerdiği, gerçekleşme olasiliğı çok düşük de olsa, bir potansiyel tehlikeye işaret etmek 
gerekir. Bu ilkenin insan hakları bakımından sakıncası, önceki andlaşmaya taraf devletlerin aralarında anlaşarak, önceki andlaşmanın sağladığı korumayı kısitlayabilmelerine olanak vermesidir. Her ne kadar gerçekleşme olasilığ çok az da olsa, bu sakınca potansiyel olarak mevcuttur ve insan haklarına saygı ilkesiyle bağdaşmamaktadır. ${ }^{23}$

Yine, Viyana Sözleşmesi'nin 30. maddesinin 4. paragrafı, sonraki andlaşmanın taraflarınun önceki andlaşmanun taraflarınun tamamun kapsamadığı varsayımı düzenlemekte ve "her iki andlaşmaya taraf olanlar arasında, sonraki andlaşmanın üstünlüğü ilkesinin uygulanacağını, fakat her iki andlaşmaya taraf bir devletle, sadece andlaşmalardan birisine taraf olan bir devlet arasında, her iki devletin tarafı olduğu andlaşma bunlann karşılıklı hak ve yükümlülüklerini tanzim eder" hükmünü içermektedir.

Insan hakları andlaşmaları bakımından söz konusu varsayım sık karşılaşılan bir durum olmakla beraber, bu kuralın da insan hakları bağdaşmazlıkları için uygun olmadığı ortadadır. Zira, daha önce de belirttiğimiz gibi insan hakları andlaşmaları bakımından, tarafların aynı olup olmamasının ve devletin insan haklarına ilişkin yükümlülüklerinin hangi devletle yaptığı andlaşmadan kaynaklandığının bir önemi yoktur. Çünkü, ilgili devlet söz konusu yükümlülükleri herhangi bir tabiyet koşulundan bağımsız olarak, ülkesinde yaşayan herkese karşı üstlenmektedir. Aksini düşünmek insan hakları ilkesine aykırılık oluşturur(ROUCOUNAS, 1987: 197; SCIOTTI, 1997: 60).

Viyana Sözleşmesi'nin, insan hakları bağdaşmazlıklarına en uygun düşebilecek çözüm kurah 58. madde hükmü gibi görünmektedir. Bu kurala göre, çok taraflı bir andlaşmaya taraf olan iki veya daha fazla devlet, 58. maddenin 1. paragrafındaki koşulları yerine getirmedikçe, kendi aralarında, söz konusu andlaşma hükümlerinin yürürlüğünü askıya almak üzere bir andlaşma yapamazlar. ${ }^{24}$ Söz konusu koşullardan en önemlisinin, tarafların kendi aralarında yapacağı andlaşmanın, söz konusu çok taraflı andlaşmanun konu ve amacıyla bağdaşması olduğu gözönüne alınacak olursa, bu kuralın insan hakları andlaşmaları bakımından, önemli bir ilke olduğu söylenebilir. Zira, çok taraflı bir insan hakları andlaşmasına taraf olan, iki devletin sözkonusu andlaşmadan kaynaklanan yükümlülüklerini azaltmak amacıyla bir andlaşma yapmaları tehlikesi her zaman mevcuttur. Iş̧e böyle iki taraflı bir andlaşma, çok taraflı insan hakları andlaşmasının konu ve amacıyla bağdaşmaz sayılacaktır. ${ }^{25}$

23 Gerçekten de, gerek BM Andlaşmasinin 1. madde 3. Paragrafta, gerekse AtHM gibi hemen bütün insan hakları sözleşmelerinin başlangıç bölümünde, insan haklanna saygının "geliştirilmesi", yani sürekli ilerleme düşüncesi vurgulanmaktadır.

24 Sözkonusu 58. maddenin 1. paragrafı, böyle bir askıya almanın andlaşmayla öngörülmesi veya yasaklanmamış olması dı̧ında, özellikle andlaşmanın konu ve amacı ile bağdaşması koşulunu aramaktadır. Ayrıca tarafların hak ve yükümlülüklerini etkilememesi gerekir.

25 Zira, genel olarak insan hakları andlaşmalarının ortak amacı, insan haklarına saygının sürekli geliştirilmesidir. Dolayısıyla, bir gerileme düşüncesi bu ilkeyle bağdaşır sayılamaz. 
Ancak, daha önce de belirttiğimiz gibi, Viyana Sözleşmesi kurallan, insan hakları andlaşmaları bakımından, her ne kadar bazı durumlarda, örneğin en elverişli hükmün uygulanmasını öngören 30 . madde 2 . paragraf veya 58 . madde hükmünde olduğu gibi, uygulanabilir bir nitelik taşısa da, çoğunlukla insan hakları alanına çok fazla uygun düşen kurallar olarak nitelendirilemez.

\section{B- Uluslararası İnsan Haklan Hukukunun Öngördüğü Çözümler}

Viyana Sözleşmesi'nin öngördüğü çatışma kurallarının insan haklan alanı bakımından pek uygulanabilir olmaması insan hakları bağdaşmazlıklarının çözümünde başka kurallar bulunmasını zorunlu kılmaktadır. Bu çözümlerden biri, insan hakları andlaşmaları arasında bir hiyerarşi olabileceği gibi, söz konusu haklar arasında maddi bir hiyerarşi de olabilir.

Bu çözümlerden birincisi konusunda, bazı yazarlar, söz konusu insan hakları andlaşmaları hyerarşisinin, evrensel andlaşmanın bölgesel andlaşmaya üstünlüğü biçiminde olabileceğini belirtmişler ise de, evrensel kuralın bölgesel kurala üstünlüğü düşüncesi çok tartışmalı ve artık savunulması zor bir hal almıştır (DUBOUIS, 1977: 275-276). Zira, bölgesel insan hakları sistemlerinin varliğı dahi, evrensel kuralın etkinliğine ve üstünlüğüne gölge düşürmektedir (DUBOUIS, 1977: 276). Her halde, böyle bir üstünlük ilkesinin, bölgesel düzenler arasındaki bağdaşmazlıklar konusunda hiçbir etkinliği olmayacaktur.

Dolayısıyla, günümüzde daha fazla geçerliliği olan ve üstünlüğü belirli bir hukuk düzenine sahip uluslararası örgütlerin kurucu andlaşmalarına tanıan ikinci görüş, uluslararası uygulamada daha çok kabul görmektedir. Gerçekten de, B.M. Şartı'nun 103. maddesi diğer andlaşmalar karşısında üstünlüğünü belirtmekte ve bu üstünlük Viyana Sözleşmesi 30. madde tarafından doğrulanmaktadır. Aynı şekilde, Avrupa Birliği de bütünleşmiş bir hukuk düzeni oluşturmakta ve Roma Andlaşması ATAD tarafından "Anayasal Şart" olarak nitelendirilmektedir (ATAD, 13 Nisan 1986, "Les Verts", Recueil, s.1336). Diğer yandan, A.İ.H.S. sistemi ayn özellikleri arzetmekte ve AlHM, söz konusu Sözleşme sistemini, taraf devletlerin diğer yükümlülükleri ne olursa olsun sayg 1 göstermek zorunda olduklan, "Avrupa kamu düzeninin anayasal enstrüman" olarak nitelemektedir (AlHM, 23 Mart 1995, "Loizidou", Seri A, No: 310; RUDH, 1995, s.130).

Söz konusu andlaşmaların anayasal niteliği, bunların sadece tarafların iç hukuklarında değil, fakat, aynı zamanda kendi aralarındaki ilişkilerde diğer andlaşmalar karşısında üstünlüğünü gerektirir.

Bu tür bir hiyerarşi dışında bir başka çözüm yöntemi, iki farklı temel hakkı düzenleyen iki insan haklanı andlaşması arasındaki bağdaşmazlığın, iki bireyin bu iki andlaşmadan doğan temel haklarının şelişmesinden 
kaynaklandığı durumlara özgü olmak üzere, temel haklar arasında maddi bir hiyerarşi oluşturulması ve böylece "daha temel veya önemli" olarak kabul edilen temel hakkı içeren insan hakları andlaşmasınun diğer andlaşmaya üstün tutulması olabilir (ROUCOUNAS, 1987:203; SCIOTTI, 1997:64). Böyle bir çözüm perspektifinde, insan hakları andlaşmasınun uluslararası hukuk düzenindeki yerini belirleyen faktör, andlaşmasınun biçimi olmayıp, onun içeriğidir. Daha önce, böyle bir duruma örnek olarak gösterdiğimiz ırk ayrumcllğına karşı korunma hakkı ile ifade özgürlüğü arasındaki çelişkiyi, AIHM, 1994'de verdiği kararda, açıkça ifade etmese de, ırk aynmcllğına karşı korunma hakkını ve dolayısıyla bunu içeren BM Irk Ayrımcliğının Ortadan Kaldırılması Sözleşmesini üstün tutarak çözmüştür. Ancak böyle bir çözüm için, insan hakları arasında bir hiyerarşi oluşturulmasına yardım edebilecek bazı ipuçlarına ihtiyaç bulunmaktadır. ${ }^{26}$

Bu ipuçlarından en önemlisi, uluslararası hukukun temel kavramlarından biri olan ve Viyana Sözleşmesi'nin 53. ve 64. maddelerinin düzenlediği "jus cogens" yani, uluslararası emredici norm kavramıdır. ${ }^{27}$ Viyana Sözleşmesi'ne göre, konusu bir emredici norma aykırı andlaşmalar batıldır. Dolayısıyla "jus cogens" oluşturan insan haklarının bir bağdaşmazlık durumunda, diğer haklardan üstün tutulması gereğinde şüphe yoktur. Her ne kadar, "jus cogens" kavramının içeriği konusunda belirsizlikler olsa da, özellikle Uluslararası Adalet Divanı'nı kararlarıyla gün geçtikçe kavramın içeriği belirginleşmektedir. ${ }^{28}$ Ancak, bugün için sadece bazı hakların "jus cogens" oluşturduğu açık bir şekilde Divan kararlarında belirtilmektedir ki bunlar yaşam hakkı, işkence ve kötü muamele yasağı, kölelik ve zorla çalıştırma yasağıdır. ${ }^{29}$

O halde, "jus cogens" oluşturan hakların, diğerlerinden üstünlüğü kesin kabul görmekle birlikte, hangi haklarnn "jus cogens" oluşturduğu noktasında belirsizlikler mevcuttur. Sadece, "insanin temel haklarinun" jus cogens oluşturduğunu kabul etsek bile, sorun çözülmemektedir. Zira bu durumda, hangi hakların "temel" hangilerinin ise bu niteliğe sahip olmadığını belirlemek gerekecektir (SCIOTTI, 1997: 66).

26 Temel hak kavramının niteliğine ilişkin bir çalışma için bkz.(CHAMPEIL-DESPLAT, 1995:323).

27 Bu kavram için bkz. (PAZARCI, 1977: 365).

28 Adalet Divanı, son olarak 8 temmuz 1996 tarihli kararında, insani hukuk kurallarınun büyük bir bölümünü "uluslararası teamül hukukunun ihlal edilemez prensipleri" olarak nitelemiştir. (C.I.J., 8 juillet 1996, Licéité de la menace ou de l'emloi d'armes nucléaires, Recueil /, s.257)

29 Divanın Soykırım Sözleşmesine Çekinceler konusunda danışma görüşünde, soykınım yasağını bir Jus cogens kurah olarak nitelemesiyle başlayan ve "Barcelona Traction" davasına ilişkin karan ile devamı eden bu süreç hakkında ayrıntılı açıklamalar için bkz. (QUOC DINH / DAILLIER / PELLET, 1999: 204). 
Gene de, bütün bu belirsizliklere rağmen, insan hakları arasında maddi bir hiyerarşi oluşturulması ve en azından, bazı hakların diğerlerinden "daha temel" bir niteliğe sahip olduğunun kabul edilmesi, bağdaşmazlıkların giderilmesinde bir çözüm yolu oluşturabilir. Gerçekten de, yaşama hakkı, işkence yasağı veya kişi özgürlüğü ve güvenliği gibi temel hakların diğerlerinden örneğin, çalışma hakkı veya mülkiyet hakkından, "daha temel" bir niteliğe sahip olduğunu söylemek mümkündür. Zira, belirttiğimiz temel haklar olmaksızın, diğerlerinin tanınmasının fazla bir anlamı olmayacaktır. Ancak, unutmamak gerekir $\mathrm{ki}$, yargıcin, temel olanla olmayan ayırd edebilmesi her zaman yukarıda verdiğimiz örnekler kadar kolay olmayacaktır (CHAMPEIL-DESPLAT, 1995: 326).

\section{SONUÇ VE DEĞERLENDIRME}

Insan hakları andlaşmaları arasında bağdaşmazlık sorunu, çok sık rastlanılan bir durum olmasa da, varlığı yadsınamayacak ve insan haklarının gelişimine paralel olarak, önemi gittikçe artan bir sorun olarak karşımıza çıkmaktadır. Aslında bu tür bağdaşmazlıkların ortaya çıkmasında, diğer koşullar yanında, yargıcn, söz konusu andlaşma normlarına doğrudan uygulanabilir bir nitelik tanıma konusundaki tutumu büyük önem kazanmaktadır. Zira, çoğu zaman ulusal yargı̧, bağdaşmazlığı çözme durumunda kalmamak için, şelişebilecek iki uluslararası insan hakları normundan birinin doğrudan uygulanabilir niteliğini reddetme yolunu yeğlemektedir.

Oysaki, bir insan hakları normunun doğrudan uygulanabilir niteliğini reddetmek, söz konusu normun uygulamadaki etkinliğinin tamamen ortadan kaldırılması anlamına gelebilecek sakıncalı bir yaklaşımdır. $O$ halde, bu tür bağdaşmazlıkların önlenmesi ve çözümüne yönelik ve daha çok uluslararası insan hakları hukuku çerçevesinde geliştirilebilecek etkin çözümler üzerinde ssrar etmek gerekir.

\section{Kaynakça}

AKILLOĞLU, Tekin (1993) "Temel Haklar ve Özgürlükler," Ders Nollan (Ankara: SBF Yayınları).

BYK, Claud (1994), "La reception des conventions internationales par le juge françals," Joumal du Droit Intemational, 94/3: 967-976.

CAPOTORTI, Francesco (1968), "Interférences dans l'ordre juridique interne entre la convention et d'autres accords Intemationaux," Actes du deuxieme colloque intemational sur la CEDH (Presse Universitaire de Bruxelles): 123-148.

CASSIN, Rene (1951), "La Declaration Universelle et la mise en oeuvre des droits de l'homme." Recueil des Cours de l'Academie de Droit Intemational, Tome 79: 311-334. 
Mahmut Göçer • Uluslararası Insan Hakları Andlaşmalarının Băgdaşmazı̆̆ı Sorunu ve Uluslararası Hukuk • 69

CHAMPEIL-DESPLAT, Veronique (1995), "La notion de droit fondamental et le droit constitutionnel français," Dalloz 1995: 323-330.

COHEN-JONATHAN, Gerard (1977). "Les rapports entre la CEDH et le Pacte des Nations Unies sur les droits civlls et politiques." Regionalisme et Universalisme dans le Droit Intemational Contemporain (Pedone): 313-337.

COHEN-JONATHAN, Gerard (1994), "La place de la CEDH dans l'ordre juridique français," Le Droit Français et la CEDH, 1974-1992, (Engel): 10-48.

COHEN-JONATHAN, Gerard (1995), "Les tribunaux administratif et les traités relatifs aux droits de l'homme," Revue Universelle des Droils de l'Homme: 120-125.

COHEN-JONATHAN, Gerard (1996), Aspects européens des droits fondamentaux, (Paris: Montchrestien).

COHEN-JONATHAN, Gerard (1994), "La place de la CEDH dans l'ordre juridique français," Le Droit Français et la CEDH, 1974-1992, (Engel): 10-48.

CONFORTI. Benedetto (1998), "L'interaction des normes internationales des droits de l'homme," La Protection des Droits de l'Homme et Le Droil International (Strasbourg: SFDL): 12-19.

DE MEYER, Jean (1990), "Brèves réflexions à propos de l'article 60 de la CEDH," Mélanges Wiarda, 1990: 124-130.

DHOMMEACIX, Jean (1989), "De l'universalité du droit international des droits de I'homme," Annuaire Français du Droit Intemational, 1989: 399-423.

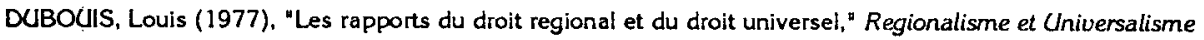
Dans Le Droit Intemational (Pedone): 263-287.

FLACISS, Jean - François (1996). "Actualité de la Convention européenne des drolts de l'homme," Actualilé Juridique, Droit Administratif: 374-388.

FLAUSS, Jean - François (1999), "Les droits de l'homme dans l'Union européenne," Les Peliles Affiches. Juillet: $147 \cdot 148$.

GALLAND, Yannick (1993), "Les conflits de traités devant le juge national," (Mémoire de DEA) (Strasbourg).

GÖÇER, Mahmut (2000), "Avrupa Birligi ve Temel Hakların Korunması," Anayasa Yargısı (Ankara: Anayasa Mahkemesi Yayınları): 386-395.

GROS-ESPIEU. Hector (1989). "La Convention americaine des droits de l'homme et la CEDH," Recueil des Cours de l'Academie de Droil Intemational: 167-420.

GÖNDÜZ, Aslan (1998), Millellerarası Hukuk, (Istanbul: Beta Yayınları).

MALINVERNI, Georges (2000), "La Sulsse et le Pacte intemational relatif aux drolts civils et politlques," Les Petites Affiches, 104: 59.

NUSS, Pierre (1996). "Le renvoi en droit international des droits de I'homme", (These de Doctorat) (Strasbourg).

PAZARCI, Hüseyin (1977), "Uluslararası Hukukta Jus Cogens Kavramı," B. Nuri Esen'e Amağan (Ankara): 365.

PAZARCl, Hüseyin (1981), "Problèmes d'incompatibilité des accords conclus par la CEE," Mélanges Reuter: 391.405 .

QUOC DINH, N. / DAILJER, P. / PELET, A. (1999), Droil International Public, (Paris: LGDJ).

RIDEAU, Jean (1991), "La coexistence des systèmes des droits fondamentaux dans la CE et ses Etats membres," Annuaire Intemational de Justice Constitutionnelle 11-64.

RIDEAU, J. / RENUCCI, J. (1997), "Dualité de la protection des droits fondamentaux," Justice: 93-106. 
ROUCOUNAS, Emmanuel (1987), "Engagements parallèles et contradjctoires," Recueil des Cours de l'Academie de Droit Intemational, 4: 16-297.

SCIOTTI, Claudia (1997), La concurrence des traités relatif aux droits de l'homme devant le juge (Bruxelles: Bruylant).

SUDRE, Frederlc (1995), Droit intemational et européen des droits de l'homme (Paris: PUF).

TEBOCL, Georges (1995), "Le juge administratif et le droit Intemational," Actualité Juridique Droit Administratif, Juin: 43.65 .

VASAK, Karl (1974), "Le drolt Intemational des droits de l'homme," Recueil des Cours de l'Academie de Droit Intemational: 407-419.

WASChMANN, Patrick (1997), "Les droits de l'homme dans le traité d'Amsterdam." Reuue Trimestrielle de Droil Européen: 885. 